\title{
Aikuiskoulutuksen ohjaus- ja tukitoiminta Saksan liittotasavallassa
}

Opinto-ohjaus on tavallisesti ymmärretty potentiaalisiin osallistujiin kohdistuvaksi toiminnaksi, jossa olemassa oleva koulutustarjonta nähdään enemmän tai vähemmän annettuna.

Arto Juhelan artikkelissa kerrotaan Saksan liittotasavallassa käynnistetyistä ja toteutetuista kokeiluprojekteista, joiden kohteena ovat olleet koulutuksellisesti huono-osaiset sekä myöhemmässä vaiheessa pienten ja keskisuurten yritysten henkilöstö.

"Valtaosa niistä ongelmista, joihin kokeiluilla on pyritty löytämään ratkaisumalleja, on löydettävissä vastineensa myös Suomesta. Toiminnan hajanainen luonne, yleiskuvan puute kokonaistarjonnasta, koulutustarjonnan ja -tarpeiden yhteensovittaminen jne. ovat varsin tuttuja ongelmia myös suomalaiselle aikuiskoulutukselle", kirjoittaa Juhela.

Seuraava esitys perustuu ensisijaisesti kahteen Saksan liittotasavallassa toteutettuun (tai käynnistettyyn) kokeiluprojektiin. Niissä eri kohderyhmille suunnattu ohjaus on liitetty osaksi koulutustarjonnan kehittämiseen tähtäävää laajempaa kokonaisuutta.

Kokeilujen yhteisenä nimittäjänä on kehittää ja arvioida erilaisia aikuiskoulutuksen ohjaus- ja tukitoimintoja. Nämä toiminnot voidaan nähdä eräällä tavalla uudenlaisena tehtäväalueena aikuiskoulutuksen kokonaiskentässä. Kyseisten toimintojen "uutuus" ei kuitenkaan varsinaisesti liity itse toimintoihin, vaan pikemminkin niiden organisointiin.

\section{Kunnallinen}

\section{aikuiskoulutusohjaus}

Vuonna 1977 käynnistettiin Saksan liittotasavallassa pääosin sikäläisen opetusministeriön (Bundesministerium für Bildung und
Wissenschaft - BMBW) rahoituksen turvin kokeiluprojekti, jonka keskeisenä tavoitteena oli kehittää toimintamuotoja, joiden avulla kyettäisiin tehokkaammin tavoittamaan koulutuksellisesti huono-osaisimmat väestönosat (lähinnä vailla ammatillista peruskoulutusta olleet työttömät tai työttömyysuhanalaiset). Tavoitteena oli myös aktivoida heidån osallistumistaan koulutukseen.

Lakisääteisesti opintoneuvonta ja -ohjaus kuuluivat ensisijaisesti työvoimaviranomaisille, mutta näiden tarjoamien palvelujen katsottiin olevan riittämättömiä ja liiaksi keskittyneitä työttömyyden välittömään hoitamiseen. Senaikaisissa tutkimuksissa oli myös osoitettu, että työttömien ja muiden erityisryhmien kiinnostus koulutukseen oli laajempaa, kuin mitä työvoimaviranomaiset olivat antaneet ymmärtää (Fischer 1982 ja Maier 1988, 206-207).

Kokeiluprojektin aloittamisen lähtökohtina 
olivat monet käytännön toiminnassa ilmenneet ongelmat. Yleisenä puutteena katsottiin ensinnäkin olleen, ettei aikuiskoulutuksen kokonaistarjonnasta ollut riittävää yleisku. vaa.

Toiseksi aikaisemmin vähäisen koulutuksen saaneiden henkilöiden ja muiden työmarkkinoiden ongelmaryhmien osallistumis. mahdollisuudet koulutukseen nähtiin vaja. vaisiksi. Tilannetta pahensi entisestään silloinen koulutuksen tarjontamalli. Koulutustarjonnan suunnittelun ongelmana oli se, että se otti puutteellisesti huomioon alueelliset ja paikalliset erityistarpeet. Ongelmaa puolestaan syvensi koulutusorganisaatioiden vălisen yhteistyön puutteellisuus koulutustarjonnan suunnittelussa ja koulutuksen markkinoinnissa (Braun $\mathcal{E}$ Fischer 1984, 13).

Näiden em. ongelmien ratkaisemiseksi tai niiden vaikutusten lieventämiseksi käynnistettiin siis kokeiluprojekti, joka toteutettiin kahdessa vaiheessa.

Ensimmäisen, vuosina 1977-79 toteu. tetun osuuden tavoitteena oli kehittää ja ko. keilla soveltuvia organisointi- ja toimintamuotoja koulutuksellisesti huono-osaisimpien väestönosien koulutusmotivaation lisää. miseksi. Kun aikuiskoulutuksen järjestämistä koskeva kritiikki oli keskeiseltä osaltaan kohdistunut toiminnan hajanaiseen luonteeseen ja kokonaiskuvan puutteeseen, katsottiin toiminnan organisoinnin olevan tarkoituksenmukaisinta järjestää yksittäisistä koulutusorganisaatioista riippumattomana kunnallisena toimintana.

Kokeilua varten perustettiin kuuteen kuntaan (Gelsenkirchen, Göttingen, Ludwigshafen, Kassel, neljä keskusta Kölnissä, Landkreises ja Aurich) yhteensä yhdeksän "opintoohjauskeskusta" (Beratungsstelle für Weiterbildung - BWB). Näissä toimi yhteensä 18 päätoimista opinto-ohjaajaa (Bildungsberater). Puolella ohjaajista oli peruskoulutuksenaan akateeminen loppututkinto kasvatus. tieteissä ja lopuilla pedagogiseen sosiaalityö. hön valmistava sosiaalialan koulutus (Emt. 23-33).

Opinto-ohjauskeskusten tehtäväkenttä jakautui neljään painopistealueeseen (taulukko 1):

1) tiedottaa yleisistä koulutusmahdollisuuksista ja lisätä koulutushalukkuutta;

2) antaa yksilöllistä opinto-ohjausta ja motivoida;

3) seurata koulutustarjontaa sekä sovittaa yhteen tarjontaa ja tarpeita;
4) kehittää koulutustarjontaa ja välittää koulutustarpeita koskevia tietoja yhteistyössä koulutusorganisaatioiden kanssa (instituutio-ohjaus).

(Braun E Erhardt 1981 ja Braun E Fischer 1984, 28-29)

Kokeiluprojektiin liittyneen toisen vaiheen (1980-83) seurantatutkimuksen tarkoituksena oli siis evaluoida kokeilulle asetettujen tavoitteiden toteutumista sekä ohjauskeskus. ten toiminnan tuloksellisuutta, mahdollisia hyötyjä ja ongelmakohtia. Lisäksi siinä kartoitettiin keskusten asiakkaiden sekä koulu. tusorganisaatioiden, työvoimatoimistojen ja eri hallinnonalojen edustajien käsityksiä ja kokemuksia toiminnasta. Erityisenä arvioinnin kohteena oli, miten erilaisissa olosuhteissa toimivat keskukset ovat käytännössä kyenneet toteuttamaan nille asetetut tavoitteet.

Kokeiluprojektin tutkimusasetelma orientoituu lähinnä toimintaan. Jatkuvan seurannan ja arvioinnin välityksellä pyrittiin ohjaa. maan ja korjaamaan toimintaa projektin koko kuusivuotisen keston ajan. Toiminnan evaluoinnin välineiksi kehitettiin kutakin tavoitetta ja tehtäväaluetta varten omat arviointimenetelmänsä ja mittarinsa. Toimintaan kohdistuneen jatkuvan seurannan lisäksi evaluointiaineistoa koottiin erillisin kyselyin ja haastatteluin.

\section{Uusi ammattikunta?}

Ohjaus- ja tukitoiminnan mahdollisuuk. sien ja toiminnan edellytysten keskeinen reunaehto liittyy niihin puitteisiin, joilla toiminta on organisoitu. Tästä syystä seurantaprojektin tehtävänä oli myös arvioida mahdollisuudet institutionalisoida kunnallisesti organisoidut ohjauskeskukset. Projektissa pyrittiin arvioimaan edellytyksiä ammatillistaa ohjaustoiminta ajatellen erityisesti päätoimisten ohjaajien pätevyysvaatimuksia, jatkokoulutusmahdollisuuksia ja tarpeita (Braun $\varepsilon$ Fischer 1984, 227-254).

\section{Toiminnan vaikutukset}

Kokeilusta saadut ensi vaiheen tulokset osoittivat, että kunnallisesti organisoidut aikuiskoulutuksen ohjauskeskukset muodostavat merkittävän välittävän tekijän aikuiskoulutuspalveluja tarjoavien instituutioiden ja palvelujen hyväksikäyttäjien välillä. Erityisesti tämä onnistui alueellisten ja paikallisten tarpeiden yhteensovittamisessa. 
Kokeilussa mukana olleissa yhdeksässä opinto-ohjauskeskuksissa asioi vuosien 1977-1982 aikana lähes 40000 henkilöä ja asiakaskäyntejä oli yli 50000 .

Kokeilun lähtökohtanahan oli tavoittaa nimenomaan koulutuksellisesti huono-osaisimmat väestöryhmät. Se näkyi myös asiakaskunnan koostumuksessa: 68 prosentilla oli pohjakoulutuksena peruskoulu (Hauptschule) ja 14 prosenttia oli vailla minkäänlaista peruskoulutusta. Ammatillista peruskoulu. tusta vailla olleita oli 47 prosenttia asiakkaista. Vastaavasti ilman minkäänlaisia kokemuksia aikuisopiskelusta oli 70 prosenttia asiakkaista.

Yksilöllisen opinto-ohjauksen keskeisenä tunnuspirrteenä ja periaatteena oli motivoida koulutukseen. Myös tässä suhteessa kokeilu antoi rohkaisevia tuloksia. Opinto-ohjauksen jälkeen puolet keskuksessa asioineista henkilöistä oli myös osallistunut aikuiskoulutukseen. Lisäksi $1 / 4$ asiakkaista ilmoitti puoli vuotta ohjauksen jälkeen aikomuksenaan olevan osallistua koulutukseen. Vastaavasti 3/4 asiakkaista katsoi ohjauksen tukeneen ja konkretisoineen merkittävästi heidän aikuis. koulutukseen osallistumistaan. Lähes kaikki (96 prosenttia) suhtautuivat varsin myöntejsesti keskusten toimintaan. (Braun $\mathcal{E}$ Fischer 1984; Fischer 1982, 228-229.)

Luvut osoittavat, että ko. toiminnalla on huomattava merkitys erityisesti aikaisemmin vähäisen koulutuksen saaneille. Tärkeänä edellytyksenä tälle on kuitenkin, ettei ohjaustoiminnot rajoitu vain tiedottamaan potentiaalisille kohderyhmille alueellisista koulutusmahdollisuuksista ja motivoimaan heitä koulutukseen. vaan että tiedot koulutustarjonnan mahdollisista puutteista ja potentiaalisten kohderyhmien osallistumisesteistä välittyvät myös koulutusorganisaatioille. $\mathrm{Ha}$ vaittuja puutteita yritetään sen jälkeen poistaa keskusten ja koulutusorganisaatioiden yhteistyönä, jotta tarjonta mahdollisimman hyvin vastaisi tavoiteltujen ryhmien toiveita ja erityisedellytyksiä.

Keskeinen osa opinto-ohjaajien tehtäviä oli siis paitsi toimia välittäjänä koulutusorganisaatioiden ja potentiaalisten kohderyhmien välillä, myös pyrkiä aktiivisesti vaikuttamaan koulutustarjonnan sisäitöön ja auttamaan koulutuksen organisoinnissa. Tämä puolestaan edellytti sekä yhteistyömuotojen kehit. tämistä keskuksen ja koulutusorganisaatioiden väillle että koulutusorganisaatioiden keskinäisen yhteistyön tiivistämistä. (Braun $\mathcal{E}$ Fischer 1984)
Myös koulutusorganisaatioiden kokemukset opinto-ohjauksesta olivat pääsääntöisesti myönteisiä. Alkuvaiheen uhkakuvat koulutuksen jatkuvasta ulkopuolisesta seurannasta ja arvioinnista sekä liiallisesta ulkopuolisesta ohjauksesta vähenivät toiminnasta saatujen kokemusten myötä. Kokeilun jälkeen 90 prosentissa organisaatioista katsottiin, että ohjaustoiminnalla voidaan oleellisesti vaikuttaa koulutustarjonnan alueelliseen kehittämiseen. (Emt., 220-223 ja Braun E Erhardt 1981, 244-245.)

\section{Ideoiden välittyminen kentälle}

Kokeilusta saadut myönteiset kokemukset eivät kuitenkaan johtaneet kattavaan kunnallisesti organisoidun opinto-ohjausjärjestelmän luomiseen 1980-luvun alusta alkaneen säästöpolitiikan takia. Toiminnan keskeinen merkitys oivallettiin kuitenkin kentällä. Siksi ohjauskeskuksia perustettiin yksittäisten koulutusorganisaatioiden yhteyteen osaksi näiden toimintaa. Näin siitäkin huolimatta, että kokeilun yhtenä keskeisenä tuloksena nähtiin, että ohjaus tulisi organisoida yksittäisistä koulutusorganisaatioista riippumatto. maksi toiminnaksi.

Tällä hetkellä toimivat opinto-ohjauskeskukset ovat Kejczin mukaan jaettavissa kolmeen tyyppiin:

1) koulutusorganisaatiokohtaiset, 2) kunnalliset ja 3) aluehallinnolliset keskukset. Hän katsoo kuitenkin, että toiminnan keskeisin ongelma kiinnittyy edelleen koulutustarjonnan hajanaisuuteen ja diffuusiuteen. Se on puolestaan seurausta ennen kaikkea koulutusorganisaatioiden välisestä kilpailusta. Epätarkoituksenmukaisen kilpailun takia ei olla kyetty luomaan keskitettyä kokonaiskuvaa alueellisesta koulutustarjonnasta sen ke. hittämiseksi. Liioin ei ole kyetty luomaan tarpeellisia kommunikaatioyhteyksiä koulutusorganisaatioiden välille, jotta alueellisen aikuiskoulutusjärjestelmän' (Weiterbildungslandschaft) kehittäminen olisi ollut mahdollista. (Kejcz 1988)

\section{Ammatillisen aikuiskoulutuksen ohjaus- ja tukitoiminnan kokeilu}

1980-luvun puolivälissä käynnistettiin BMBW:n toimesta uusi aikuiskoulutuksen ohjaukseen liittyvä kokeilu, jonka tutkimuksellisesta seurannasta vastaa Saltzgitterissä toimiva Friedrichsdorfer Büro für Bildungsplanung. 


\begin{tabular}{|c|c|c|}
\hline & Tavoite & Tehtävät \\
\hline 1) & $\begin{array}{l}\text { - Koulutuksesta ja sen mah- } \\
\text { dollisuuksista sekä keskuksen } \\
\text { omasta toiminnasta tiedottami- } \\
\text { nen } \\
\text { - Alueellista koulutustarjon- } \\
\text { taa koskevan kokonaiskuvan } \\
\text { selkiyttäminen }\end{array}$ & $\begin{array}{l}\text { 1. Erilaisten (kohderyhmäspe- } \\
\text { sifien) tiedonvälityskanavien } \\
\text { hyödyntäminen } \\
\text { 2. Eri kohderyhmille suunnattu } \\
\text { tiedottaminen ja "markkinointi" }\end{array}$ \\
\hline 2) & $\begin{array}{l}\text { - Koulutustarjontaa koskeva } \\
\text { tiedottaminen, ohjaus ja neu- } \\
\text { vonta } \\
\text { - Motivointi koulutukseen } \\
\text { osallistumiseksi } \\
\text { - Osallistumis(halukkuud)en } \\
\text { tukeminen ja osallistumisestei- } \\
\text { den alentaminen } \\
\text { - Koulutuksellisesti huono- } \\
\text { osaisten osallistumismahdolli- } \\
\text { suuksien parantaminen }\end{array}$ & $\begin{array}{l}\text { 1. Yleinen neuvonta ja ohjaus; } \\
\text { avustaminen ja ohjaus yleissi- } \\
\text { vistävää ja ammatillista perus- } \\
\text { koulutusta koskevassa päätök- } \\
\text { senteossa; yleisestä koulutus- } \\
\text { tarjonnasta, sisäänpääsyvaati- } \\
\text { muksista sekä koulutuksen } \\
\text { ajankohdista, kestosta ja kus- } \\
\text { tannuksista informointi; opinto- } \\
\text { sosiaaliseen tukeen littyvistä } \\
\text { asioista informointi sekä tukemi- } \\
\text { nen koulutukseen osallistumi- } \\
\text { seksi }\end{array}$ \\
\hline 3) & $\begin{array}{l}\text { - Tietojen kokoaminen alueel- } \\
\text { lisesta koulutustarjonnasta ja } \\
\text { koulutusta antavista organisaa- } \\
\text { tioista } \\
\text { - Koulutustarpeiden ja tarjon- } \\
\text { nan yhteensovittaminen } \\
\text { - Tietojen muokkaaminen } \\
\text { koulutustarjonnan suunnittelua } \\
\text { varten (erityisesti eri kohderyh- } \\
\text { mille suunnattu tarjonta) }\end{array}$ & $\begin{array}{l}\text { 1. Kaikkien eri koulutusorgani- } \\
\text { saatioiden tarjontaa koskevien } \\
\text { tietojen kokoaminen ja doku- } \\
\text { mentointi } \\
\text { 2. Eri kohderyhmien koulutus- } \\
\text { tarpeiden sekä yksilöohjaukses- } \\
\text { sa esiintulleiden tarjonnan puut- } \\
\text { teiden ja osallistumisesteiden } \\
\text { selvittäminen }\end{array}$ \\
\hline 4) & $\begin{array}{l}\text { - Avustaminen (ja ohjaus) alu- } \\
\text { eellisten koulutusorganisaatioi- } \\
\text { den yleisen tarjonnan ja eri koh- } \\
\text { deryhmille tarkoitetun koulutuk- } \\
\text { sen suunnittelussa sekä aikai- } \\
\text { semmin vähäisen koulutuksen } \\
\text { saaneiden väestönosien osallis- } \\
\text { tumismahdollisuuksien paranta- } \\
\text { minen } \\
\text { - Koulutustarjonnan aukkojen } \\
\text { ja paikallisten puutteiden vä- } \\
\text { hentäminen/ poistaminen } \\
\text { - Koulutusta antavien laitos- } \\
\text { ten (yleissivistävä, ammatillinen } \\
\text { jne.) yhteistyön kehittäminen }\end{array}$ & $\begin{array}{l}\text { 1. Eri kohderyhmien osallistu- } \\
\text { mishalukkuutta ja -esteitä sekä } \\
\text { ohjauskeskusten toimintaa ja } \\
\text { tehtävi koskevien tietojen välit- } \\
\text { täminen koulutusorganisaatioil- } \\
\text { le } \\
\text { 2. Koulutusorganisaatioiden } \\
\text { ohjaus opiskelijahankinnan ke- } \\
\text { hittämiseksi } \\
\text { 3. Koulutusorganisaatioiden } \\
\text { ohjaus koulutuksen tarjonnan } \\
\text { suunnittelussa ja tarjontaan liit- } \\
\text { tyvien osallistumisesteiden vä- } \\
\text { hentämisessä/poistamisessa }\end{array}$ \\
\hline
\end{tabular}


3. Koulutusoppaan ja julkaisujen laatiminen sekä informaatiopalvelun kehittäminen eri kohderyhmille suunnatusta tarjonnasta

- Esitteistä, julisteista, ilmoituksista ym. mainonnasta huolehtiminen sekä informaatiopisteiden rakentaminen

- Yhteistyö eri tiedonvälityskanavien kanssa (lehdistö, radio, TV)

- Ohjauskeskusten toiminnan esittely alueellisille/paikallisille koulutusorganisaatioille, yhteistöille ym.

- Yhteistyö koulutuksen järjestäjien, työvoima-, sosiaaliym. viranomaisten sekä muiden ohjauskeskusten kanssa

- Ryhmätyöskentelystä vastaaminen sekä sosiaalipedagoginen huolehtiminen opiskelijoista

- Toiminnan kannalta relevantin aineiston (koulutushalukkuus, ohjaustoiminta, kohderyhmien koostumus) kokoaminen ja arviointi

3. Koulutustarjonnan puutteiden määrittäminen alueellista koulutustarjontaa koskevan analyysin ja arvioinnin välityksellä

4. Koulutustarpeita ja tarjonnan puutteita koskevan tiedon välittäminen koulutusorganisaatiolle ja kunnille
- Ohjauksen kannalta relevantin tarjontaa koskevan tiedon jatkuva kokoaminen, systematisointi ja arviointi

- Vuosittaiset arviot koulutustarpeista ja tarjonnan puutteista - Alueellisen koulutustarjonnan ja sen hyödyntämisen (osallistumisrakenteet, alueellinen jakauma) selvittäminen

- Muistioiden ym. selontekojen laatiminen koulutusta antaville laitoksille, hallinnolle ja poliitikoille

- Kahdenkeskinen yhteistyö koulutusorganisaatioiden kanssa

- Koulutusorganisaatioiden välisen keskinäisen yhteistyön käynnistäminen (tarjonnan suunnittelussa, työnjaossa jne.) - Osallistuminen opetussuunnitelmien kehittämiseen eri kohderyhmiä varten

- Kouluttajakoulutus tarjonnan kehittämiseksi

- Yhteistyö koulutusorganisaatioiden ulkopuolisten eri tahojen ja elinten kanssa 
Kun 1970-luvun lopulla aloitetun kokeilun keskeisenä lähtökohtana oli lisätä aikaisem. min vähäisen peruskoulutuksen saaneiden henkilöiden osallistumismahdollisuuksia erityisesti ammatilliseen peruskoulutukseen, pyrittiin jälkimmäisessä kokeilussa tavoittamaan ensisijaisesti pienten ja keskisuurten yritysten henkilöstö. Vastaavasti painopistettä siirrettiin myös peruskoulutuksesta ko. yritysten henkilöstön lisäkoulutukseen.

Perustavoitteiltaan kumpainenkin kokeilu on kuitenkin samanlainen: arvioida aikuiskoulutuksen ohjauksen hyödyntämismahdollisuuksia koulutustarjonnan ja koulutuksellisen yhteistyön alueellisessa kehittämisessä.
Syksyllä 1986 aloitetun kokeilun erityispainopisteenä oli uuden teknologian käyt. töönotto PKT-yrityksissä. Lähtökohtana oli ajatus, että työntekijöiden puutteellisen osaamisen takia ei uuden teknologian suo. mia mahdollisuuksia hyödynnetä riittävästi. Erityiseksi ongelmaksi tämä nähtiin PKT-yrityksille, joiden mahdollisuudet järjestää lisä. koulutusta ovat rajailiset. Tätä aukkoa ei kuitenkaan oltu kyetty täyttämään alueen aikuiskoulutuksen tarjonnalla, joka ei vastan. nut yritysten erityistarpeita.

Perusongelma paikantui siis jälleen koulutustarjonnan hajanaisuuteen ja kattavan yleiskuvan puutteeseen. Näiden ongelmien voittamiseksi aloitettiin kokeilu seitsemässä aikuiskoulutusorganisaatiossa erilaisten oh. jauksen organisointimuotojen arvioimiseksi.

Kuvio 1.

\section{Aikuiskoulutuksen tuki- ja ohjaustoimintojen rakenne}

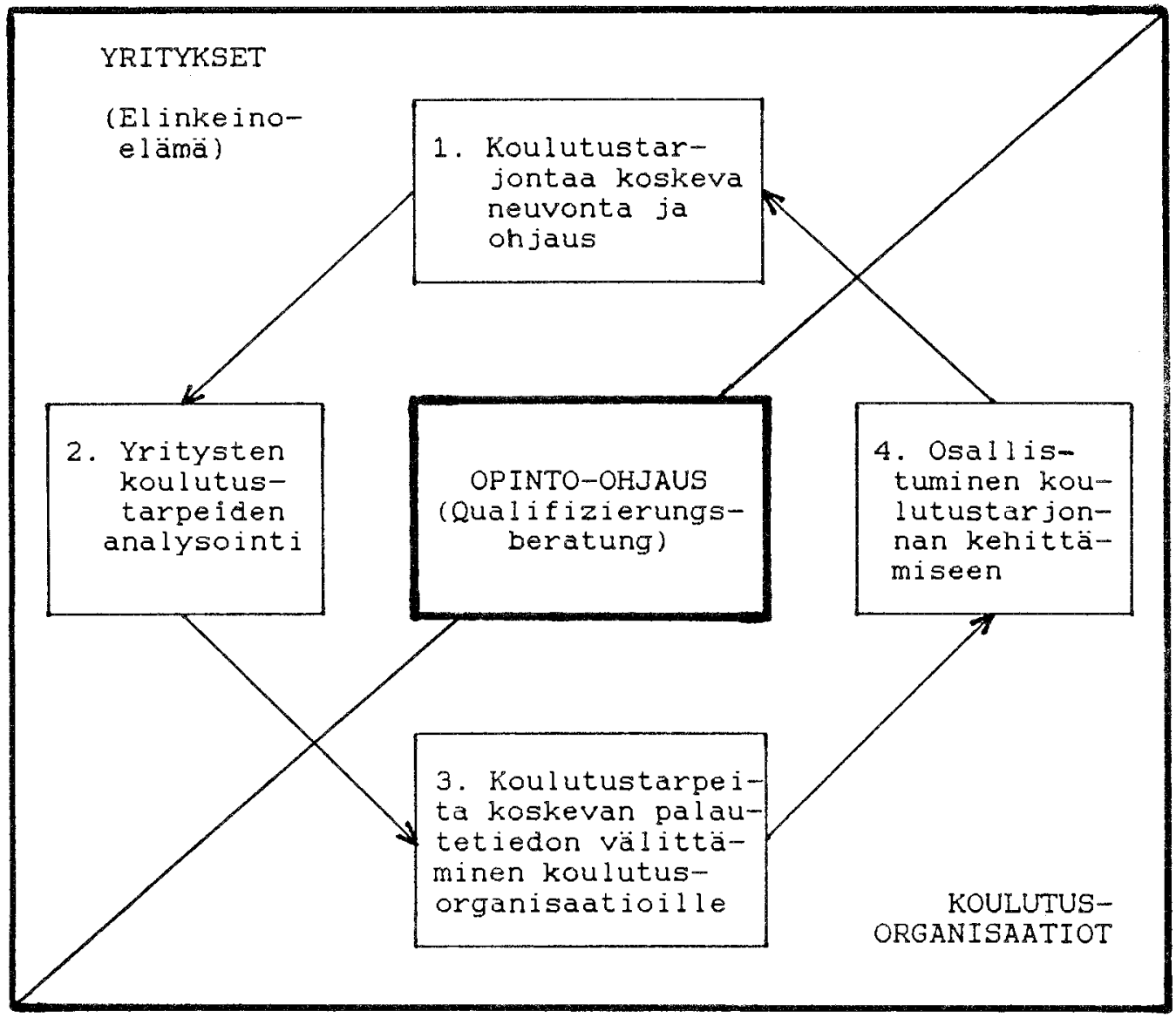


Kokeiluun osallistuvat seuraavat koulutusorganisaatiot:

- Überbetriebliches Ausbildungszentrum Elmshorn

- Berufsbildungsstätte Westmünsterland $\mathrm{GmbH}$ für Handwerk und Industrie in Ahaus

- Informationstechnik.Zentrum Köln

- Niedersächsische Volkhochschule e.V., Hannover, kokeilualueena Saltzgitter

- Gesamthochschule Kassel, Kontakstelle für wissenschaftliche Weiterbildung

- Handwerkskammer der Pfalz, Kaiserslautern

- Berufsbildungszentren der Bayerischen Arbeitgeberverbände e.V., München, kokeilualueena Regensburg. (Koch $\varepsilon$ Kraak 1989a ja 1989b)

\section{Ohjauksen tehtävät}

Kokeilussa aikuiskoulutuksen tuki- ja ohjaustoiminnot (Qualifizierungsberatung), joiden perimmäisenä tavoitteena on koulutus. tarpeiden ja tarjonnan yhteensovittaminen, jakautuvat neljään tehtäväalueeseen (kuvio 1):

1) yrityksille ja potentiaalisille osallistujille suunnattu neuvonta ja ohjaus alueellisesta koulutustarjonnasta;
2) yritysten koulutustarpeiden analysointi;

3) palautetiedon välittäminen yritysten koulutustarpeista sekä

4) osallistuminen koulutustarjonnan sisällölliseen ja organisatoriseen kehittämistyöhön. (Koch \& Kraak 1989a, 15-17.)

\section{Organisoinnin eriytyminen}

Kokeilussa mukana olevissa eri koulutu. sorganisaatioissa on tuki- ja ohjaustoiminnot organisoitu jossain määrin toisistaan poikke. avasti. Osaltaan tämä näkyy myös siinä, että em. tehtäväalueet painottuvat eri tavoin koulutusorganisaatiosta riippuen.

Kehittämis- ja kokeiluhankkeen tähänastisten kokemusten perusteella näyttäisi muodostuneen kolme aikuiskoulutuksen tuki ja ohjaustoiminnan perustyyppiä. Nämä voivat painottua 1) koulutustarjonnan kehittämiseen, 2) alueellisen elinkeinopolitiikan tukitoimintaan tai 3) osaksi organisaation laajempaa toimintakokonaisuutta. Luokittelussa on kuitenkin kyse vain painotuksista; kussakin yksittäistapauksessa on löydettävissä aineksia myös muilta toiminta-alueen lohkoilta (kuvio 2). (Koch \& Kraak 1989a, 22-24 ja 1989b, 16-19.)

Kuvio 2.

\section{Kokeilukohteiden sijoittuminen toiminnan eri painopistealuille}

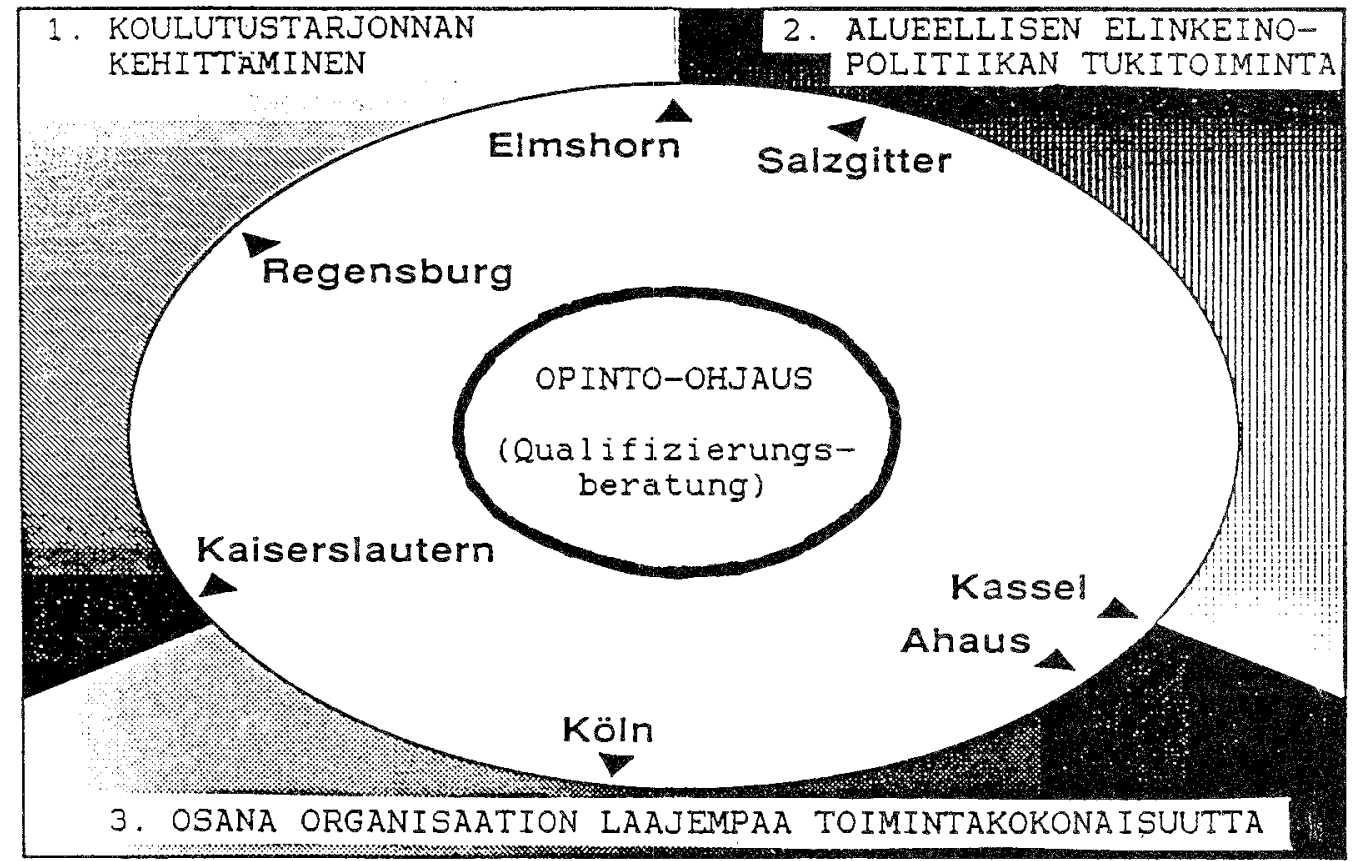

Lähde: Koch $\mathcal{E}$ Kraak 1989a, 41. 
Koulutustarjonnan kehittämisellä (ks. kuvio 2 , kohta 1) pyritään mukauttamaan tarjonta mahdollisimman hyvin tarpeita vastaa. vaksi, mikä puolestaan on edellyttänyt erilaisten tarvearviointien metodista kehittelyä. Kirjallisista yrityskyselyistä ollaan siirrytty työpaikoilla suoritettuihin haastatteluihin. Lisäksi on jonkin verran käytetty myös vaativampia työtoiminnan analyyseja.

Peruslähtökohtana on ollut, että laajem. pien koulutustarvekartoitusten sijasta on py. ritty välittömien yrityskontaktien kautta räätälöimään yksilölliset ratkaisut kunkin yrityk. sen erityistarpeiden mukaisesti. Tämä on merkinnyt yhtäältä yritysten sisäisen koulutuksen lisääntymistä ja yhtäältä muutospaineita standardinomaiselle koulutustarjonnalle. Mittatilauksena toteutettu koulutus on edellyttänyt yhteistyömuotojen ja kommunikaation kehittämistä kaikkien kolmen osapuolen välillä. Toisaalta suuntautuminen yri. tyskohtaiseen koulutukseen on merkinnyt myös koulutuskustannusten kasvua $\mathrm{mm}$. siksi, että kouluttajien edellytetään osallistuvan suunnitteluun mahdollisimman varhaisessa vaiheessa.

Koulutustarjonnan kehittämistoiminnan tavoitteena on siis pyrkiä toimimaan eräänlaisena muutosagenttina suhteessa sekä koulutusta hyödyntäviin yrityksiin että koulutusta tarjoaviin organisaatioihin.

Saksan liittotasavallan koulutuspolitiikan (ks. kuvio 2, kohta 2) yleisenä lähtökohtana on, että alueelliset aikuiskoulutuskeskukset rahoittavat itse oman toimintansa. Tästä syystä myös ohjaus- ja tukipalvelut on tavallisesti rahoitettu joko suoraan maksullisena palvelutoimintana tai kurssimaksuihin sisälly. tettynä. Alueellisen elinkeinopolitiikan edistämiseksi on kokeilussa kuitenkin pyritty etsimään myös toimintamuotoja yhteistyössä työvoimaviranomaisten kanssa. Julkisin varoin tuetun toiminnan tavoitteena on ollut paitsi kehittää yritysten toimintaedellytyksiä, myös alentaa yksittäisten koulutettavien osallistumisesteitä ja huolehtia aktiivisesta työllisyyspolitiikasta.

Toiminnasta saatujen kokemusten myötä on havaittu, ettei PKT-yritysten ongelmana ole pelkästään tarkoituksenmukaisen koulutuksen saavutettavuus ja etteivät yritykset ole kiinnostuneita pelkästään erillisistä koulutusinterventioista. Yritykset tarvitsevat koulutuksellisen ohjauksen lisäksi $\mathrm{mm}$. erilaisia teknologia ja yrityspalveluja. Tästä syystä eri tuki- ja ohjaustoiminnot pyritään mahdolli- suuksien mukaan liittämään laajemmaksi kokonaisuudeksi (ks. kuvio 2, kohta 3). Niiden avulla voitaisiin ratkaista yrityksissä käy. tännössä ilmeneviä monitahoisia ongelmia.

Tavoitteena on luoda alueellisista aikuis. koulutuskeskuksista asiantuntija- ja palvelu. keskuksia myös teknologisissa ja työn organisointiin liittyvissä kysymyksissä. Tämä luo edellytykset niveltää muut tukipalvelut yrityskohtaiseen koulutukseen, mitä mahdollisuutta ei suurilla valtakunnallisilla koulutus. keskuksilla aina välttämättä ole.

Muista tuki- ja ohjaustoimintojen integrointiin liittyvistä toiminnoista voidaan mai. nita $\mathrm{mm}$. tietopalvelut tuoteinnovaatioista se. kä näihin liittyvien lisenssien välittäminen.

Kokeilusta saadut tähänastiset tulokset ovat osoittaneet, että ammatillisen aikuis. koulutuksen ohjaus- ja tukitoimien avulla voidaan oleellisesti edistää ammatillisen aikuiskoulutuksen käytännön toimintaa. Koulutustarjonnan optimoinnin ja yritysten erityistarpeiden yhteensovittamisen ohella toiminnan ehkä merkittävin vaikutus on ollut siinä, että se on lisännyt yrityksissä tietoisuutta aikuiskoulutuksen mahdollisuuksista erilaisten ongelmien ratkaisemiseksi (Bundesminister ... 1989, 143.)

\section{Aikuiskoulutuksen ohjaus Suomessa?}

Valtaosalle niistä ongelmista, joihin edellä esitellyillä kokeiluilla on pyritty löytämään ratkaisumalleja, on löydettävissä vastineensa myös Suomesta. Toiminnan hajanainen luonne, yleiskuvan puute kokonaistarjonnasta, osallistumisen kasautuminen, koulutustarjonnan ja tarpeiden yhteensovittaminen jne. ovat varsin tuttuja ongelmia myös suomalaiselle aikuiskoulutukselle.

Ongelmien merkitys on ymmärretty myös suomalaisessa aikuiskoulutuksen kentässä. Lukuisiin kuntiin on perustettu aikuiskoulu. tusasiamiehen virka, joiden tehtäväkuva muistuttaa varsin pitkälti saksalaisten (kunnallisten ym.) ohjauskeskusten tehtäviä (esimerkiksi Siltanen 1989). Nykyisellään toiminta on kuitenkin vielä siinä määrin uutta, ettei asiamiesten toimenkuvat ole toistaiseksi kaikilta osin vielä selkiytyneet.

Aikuiskoulutuksen viimeaikaisessa kehityksessä on joitakin piirteitä, jotka saattavat entisestään syventää koulutuksen solmu- 
kohtia. Erityisesti ammatillisen aikuiskoulutuksen kapasiteetti on kasvanut merkittäväs ti viime vuosina, kun lukuisiin ammatillisiin oppilaitoksiin on perustettu aikuiskoulutus tai kurssiosastot. Lisäksi aikuiskoulutuksen ohjaus- ja rahoitusjärjestelmiä ollaan uudista. massa ns. kysyntämallin mukaiseksi.

Mm. nämä tekevät keskitetysti hallitun ko. konaiskuvan koulutuksen alueellisesta tarjonnasta ja erityistarpeista entistäkin merkityksellisemmäksi, jotta koulutuksen kokonaistarjonnassa vältyttäisiin epätarkoituksen. mukaiselta kilpailulta ja päällekkäisyydeltä. Toimivan koulutuksellisen yhteistyön välityksellä olisivat myös koulutustarjonnan mahdolliset puutteet helpommin havaittavissa.
Vastaavasti tarpeiden ja tarjonnan yhteensovittaminen on muodostunut entistä merkittävämmäksi ongelmaksi, joka edellyttää uudenlaisia toimintatapoja ja käytäntöjä.

Yksi aikuiskoulutuksen ikuisuuskysymyksiä on osallistumisen kasautuminen. Ongelma ei luonnollisestikaan ole ratkaistavissa pelkästään ulkoisella ohjaus- ja tukitoiminnalla. Tarvitaan uudistuksia, jotka todellisessa mielessä luovat pohjan osallistua koulutukseen. Kuitenkin Saksan liittotasavallassa saadut kokemukset antavat varsin vahvoja viitteitä siitä, että myös ko. toiminnalla voidaan merkittävästi aktivoida koulutuksellisesti huono-osaisten väestönosien osallistumista koulutukseen.

\section{LÄHTEET}

Braun, Joachim \& Ehrhardt, Peter 1981: Kommunale Weiterbildungsberatung: bedürfsorientierte Angebotsplanung und Angebotsgestaltung. Teoksessa Bayer, M. ym. (Hrsg.) 1981: Bedarfsorientierte Entwicklungsplanung in der Weiterbildung. Opladen: Leske-Verlag.

Braun, Joachim \& Fischer, Lutz 1984: Bedarfsorientierte Beratung in der Weiterbildung. Technologische Entwicklung und Arbeitslosigkeit als Herausforderung für die Weiterbildungsberatung. Deutsches Institut für Urbanistik. München: Lexika-Verlag. Bundesminister für Bildung und Wissenschaft (Hrsg.) 1989: Berufsbildungsbericht 1989. Schriftenreihe Grundlagen und Perspektiven für Bildung und Wissenschaft 24. Bonn.

Fischer, Lutz 1982: Weiterbildung als kommunale Aufgabe. Empfehlung zur Einrichtung von Beratungsstellen für Weiterbildung in Kommunen. Gewerkschaftliche Bildungspolitik 1982, 8, 227-230.
Kejck, Yvonne 1988: Weiterbildungsberatung. Eine Untersuchung im Auftrag des Bundesministers für Bildung und Wissenschaft. Arbeitsgruppe für empirische Forschung (AfeB). Heidelberg.

Koch, Johannes \& Kraak, Ralf 1989a: Qualifizierungsberatung zur Verbesserung des Weiterbildungsangebots für kleine und mittlere Betriebe. Scwerpunkt: Neue Techniken. Friedrichsdorfer Büro für Bildungsplanung: Saltzgitter.

Koch, Johannes \& Kraak, Ralf 1989b: Vom Weiterbildungsträger zum regionalen Dienstleistungszentrum für die mittelständische Wirtschaft. Berufsbildung in Wissenschaft und Praxis 1989, 18, 6, 13-19.

Maier, Friedrike 1988: Beschäftigungspolitik vor Ort. Die Politik der kleinen Schritte. WZB, Forschungsschwerpunkt Arbeitsmarkt und Beschäftigung. Berlin: Edition Sigma.

Siltanen, Päivi 1989: Development of adult education in Tampere. Adult Education in Finland 1989, 26, 2, 5-10. 


\title{
AIKUISKASVATUS
}

\author{
The Finnish Journal of Adult Education \\ Vol.10, 4/90 \\ ISSN 0358-6197 \\ Summary
}

Juhela Arto 1990. Aikuiskoulutuksen ohjaus- ja tukitoiminta Saksan liittotasavallassa. - Opinto-ohjaus on tavallisesti ymmärretty potentiaalisiin osallistujiin kohdistuvaksi toiminnaksi, jossa olemassa oleva koulutustarjonta nähdään enemmän tai vähemmän annettuna. Artikkeli perustuu ensisijaisesti kahteen Saksan liittotasavallassa toteutettuun (tai käynnistettyyn) kokeiluprojektiin. Niissä eri kohderyhmille suunnattu ohjaus on liitetty osaksi koulutustarjonnan kehittämiseen tähtäävää laajempaa kokonaisuutta. Kokeilun kohteina ovat olleet koulutuksellisesti huono-osaiset sekä myöhemmässä vaiheessa pienten ja keskisuurten yritysten henkilöstö.

Aikuiskasvatus 10,4.
Juhela Arto 1990. The guidance and support given in adult education in the Federal Republic of Germany.

- Study counselling is usually understood as being an activity aimed at potential participants in the course of which the current educational provision is more or less taken for granted. The article is based mainly on two experimental projects implemented (or initiated) in the Fed. eral Republic of Germany. In the course of these projects, the guidance given to the various target groups has been made a part of a larger whole aimed at the development of the educational provision. The target groups in these experiments have comprised the educa. tionally deprived and in a later stage the personnel of small and medium sized enterprises. Aikuiskasvatus 10,4. 